Indonesian Journal of Nutrition and Dietetics Vol. 5, Issue 2, 2017: 66-76
Available online at: http://ejournal.almaata.ac.id/index.php/IJND DOI : http://dx.doi.org/10.21927/ijnd.2017.5(2).66-76

\title{
Fiber intake and physical excercise contributed to blood glucose level in outpatients with type 2 diabetes mellitus
}

\author{
Rijanti $^{1}$, Rizqi Dwi Anisa ${ }^{1}$ \\ ${ }^{1}$ Majoring in Nutrition of Health Polytechnic of Banjarmasin Health Ministry, \\ Kalimantan Selatan, Indonesia \\ *Corresponding author: rijanti63@yahoo.com
}

\begin{abstract}
Background: Education, diet plan, pharmacologically and physical exercise are factors that can change the status of blood glucose levels. A low level of knowledge can affect the wrong dietary habit. DM patients are suggested to consume fiber as much as $25 \mathrm{~g} /$ day.

Objectives: The article aimed to analyze the level of knowledge, fibers intake and physical exercise of type 2 DM patients' blood glucose levels at Internal Disease Polyclinic of RSUD Ulin Banjarmasin.

Methods: This study used observational analytics method with cross- sectional design. The population of this study were type 2 DM patients and had been checked for the fasting blood glucose levels at Internal Disease Polyclinic of RSUD Ulin Banjarmasin in April 2017. There were 47 samples that were taken by using purposive sampling. To collect food intake data, questionnaire food recall. The data analysis used Spearman's correlation test rank and regesi logistic (mulivariate) with 95\% of confidence level.

Results: The result showed that $66 \%$ of blood glucose levels were uncontrolled, $40.4 \%$ of knowledge level were average, $68.1 \%$ of fibers intake was less, and $57.4 \%$ of physical exercises were less. Level of knowledge, intake of fiber, physical exercise contributed to blood glucose levels. The level of glucose levels closeness to the knowledge level was very strong with $r=-0.79$ and that of to fiber intake and physical exercise were moderate level with $r=-0.47$ and $r=-0.38$.

Conclusion: Fiber intake and physical exercise are significantly associated with blood glucose in patients with type 2 diabetes outpatient.
\end{abstract}

KEYWORDS: Type 2 DM, the level of knowledge, fiber, physical exercise, blood glucose.

\section{INTRODUCTION}

Diabetes mellitus (DM) is a group of metabolic diseases characterized by hyperglycemia that occurs due to abnormalities of insulin secretion, insulin work or that correlates with blood glucose levels. High blood glucose levels will gradually lead todamage the blood vessels and diseases, such as in: heart, kidney, stroke and others. World Health Organization (WHO) defined diabetes mellitus as a collection of anatomical and chemical problems from the addition of factors in which there is absolute or relative insulin deficiency and impaired insulin function(1).

The number of DM patients as many as 366 million in 2011 and increased to 387 million in 2014. This number is estimated to almost around grow to 592 million in 2035. The number of deaths that occurred in 2014 as much as 4.9 million of inhabitants. where there is one death of DM sufferers in the world every seven seconds. Indonesia ranks fourth of the largest number of DM patients with a prevalence of $8.6 \%$ of the total population, and $\mathrm{WHO}$ predicts the increase in the number of people with DM in Indonesia from 8.4 million in 2000 to about 21.3 million in 2030(3). The incidence of DM cases in South Kalimantan Province over the age of 14 is estimated to be $1.4 \%$ (38.113 inhabitants) and $0.6 \%$ (16,334 people) experienced symptoms of DM(4).

For 2 years in a row, in 2014 type 2 DM was ranked $8^{\text {th }}$ with 115 people, and in 2015 there was a rise to rank $7^{\text {th }}$ with 204 people. In the recap of the results in January-August 2016 in the clinic RSUD Dr. Moewardi Surakarta obtained that the ranking of type 2 diabetes mellitus has increased to rank $2^{\text {nd }}$ with 356 people(5).

Low levels of knowledge will affect the wrong diet that eventually leads to an increase in blood 
glucose levels. About $75 \%$ of diabetics did not follow the recommended diet (5). Fiber intakewas still less than the recommended number, with an average fiber intake of $13.22 \mathrm{~g}$ per day. Intake of fiber as much as $25 \mathrm{~g}$ per day was recommended for DM patients in Indonesia (6).

Another factor that can lower blood glucose levels is by removing glucose from the bloodstream that will be used as an energy source. Previous study reported that patients with inactive physical activity had the risk to suffer from DM. In internal polyclinic patient from 4 hospitals in South Kalimantan.

The preliminary study conducted in September 2016 at Ulin Banjarmasin Hospital of there were 6 patients with type $2 \mathrm{DM}$, found that all patients had blood glucose $>126 \mathrm{mg} / \mathrm{dL}$. The direct interviews on patients about food that is not allowed and regulary of physical exercise had also been done, it showed that 4 out of 6 respondents said that sweet foods are not allowed food and 3 of 6 respondents do regularly exercise. The aim of this research wasto analyze the level of knowledge, fiber intake and physical exercise on blood glucose levels of patients with type 2 DM in Ulin Polyclinic hospital in Banjarmasin 2017.

\section{MATERIALS AND METHODS}

This research was an observational analytic study with cross sectional design. It has been done escaped research ethics with the norm 115 / IV-Research / RSUDU / dated 3 April 2017. This research was conducted at Ulin Polyclinic of Ulin Banjarmasin Hospital on April $3^{\text {rd }}$ - April $28^{\text {th }}, 2017$. The population in this research is type $2 \mathrm{DM}$ out patient. Samples were to 47 people.

The sample technique used was purposive sampling. The sampleshould meet the insclusion criteria, such as: outpatient patient with type 2 DM, the patient can communicate well and clearly, patients with aged $\geq 40$ years to 70 years, patients who have been examine fasting blood glucose levels, patients are willing to be respondents.

Exclusion criteria of samples were: Patients with acute and chronic complications (diabetic retinopathy, nephropathy, diabetic neuropathy, gangrene, diabetic ulcers, etc.), pregnant patients and patients who consume food early in the morning before laboratory tests.

Education was categorized based on primary education (graduated from primary school), secondary education (graduated from junior high schoolhigh school / senior high school / equivalent high school / equivalent) and higher education that is graduated from academy, institute / equal according to Law No. 20 of 2003 (8). The results of IMT were classified into:

$\begin{array}{lll}\text { - } & \text { Severe Wasting } & :<17.0 \\ \text { - } & \text { Wasting } & : 17-18.5 \\ \text { - } & \text { Normal } & :>18.5-25.0 \\ \text { - } & \text { Overweight } & :>25.0-27.0 \\ \text { - } & \text { Obesity } & :>27.0\end{array}$

Source: Supariasa, 2013

Blood glucose level was included in under controlled category when $<126 \mathrm{mg} / \mathrm{dL}$ and uncontrolled when $\geq 126 \mathrm{mg} / \mathrm{dL}$ (3). The level of knowledge was included in good category if the correct answers were, $76-100 \%$, while $56-75 \%$ and $<56 \%$ were chategorized in fair and poor. (9). Fiber intake was included in either category of good and poor when they consumed $\geq 25 \mathrm{~g} /$ day and during $<25 \mathrm{~g} /$ day (3). Physical exercise was good in either category when they did the exercise $\geq 3-4 x$ / week and duration $\geq 30$ minutes, less if the frequency was insufficient or insufficient duration, or insufficient frequency and duration (10). Data were collected using questionnaire and $1 \times 24$ hours food recall. The validity and reliability of variable knowledge, fiber consumption, physical exercise were also done.

Data analyzed using computer program in univariate, bivariate and multivariate analysis. Univariate analysis was used to perform analysis on each variable studied to know the frequency of distribution. Bivariate analysis was done to determine the effect of existing variables by using Spearman rank correlation test using computer with 95\% confidence level. Multivariate analysis used computer program with logistic regression test to get the interaction of the variables studied (11) 


\section{RESULTS}

RSUD Ulin Banjarmasin is a General Hospital with Class A classification. Itis a referral center hospital in Kalimantan Selatan, Kalimantan Tengah and Kalimantan Timur. In the polyclinic of internal medicine, there is an endocrine polyclinic section. The task performed in the endocrine polyclinic is to monitor the prolonged development of outpatient patients and to provide new and advanced diagnosis and treatment of new patients. The number of samples is 47 people.

\section{Characteristics of Respondents}

Characteristics of Respondents by characteristics can be seen in the following Table 1:

Table 1. Characteristics of respondents

\begin{tabular}{lcc}
\hline \multicolumn{1}{c}{ Characteristics } & $\mathbf{n}$ & $\%$ \\
\hline Age (years) & 6 & 12.8 \\
$36-45)$ & 17 & 36.2 \\
$(46-55)$ & 24 & 51.1 \\
$56-65)$ & & \\
Sex & 20 & 42.6 \\
$\quad$ Male & 27 & 57.4 \\
Female & & \\
Occupation & 11 & 23.4 \\
$\quad$ Private Employee & 9 & 19.1 \\
$\quad$ Government Employee & 2 & 4.3 \\
$\quad$ Labor & 21 & 44.7 \\
$\quad$ Not Working & 4 & 8.5 \\
$\quad$ Retired EMployee & & \\
Education & 6 & 12.8 \\
$\quad$ Senior High School & 24 & 51.1 \\
Junior High School & 17 & 36.2 \\
$\quad$ Tinggi & & \\
Nutritional Status & 1 & 2.1 \\
$\quad$ Severe Wasting & 2 & 4.3 \\
Wasting & 30 & 63.8 \\
Normal & 5 & 10.6 \\
Overweight & 9 & 19.1 \\
Severe Overweight & 47 & 100 \\
\hline Total &
\end{tabular}

Source : Processed Prime Data, 2017

Based on Table 1, it can be seen that most of respondents had the age 56-65 years as many as 24 people $(51.1 \%)$.

The sex of female respondents was 27 (57.4\%) people. The occupation of the respondents was the most not working as many as 21 people (44.7\%) and had the most jobs consisting of merchants and civil cervants, those were 11 people $(23.4 \%) 9$ people $(19.1 \%)$ respectively. The level of education of most respondents was junior and high school, those were as many as 24 people $(51.1 \%)$. The nutritional status of the respondents was mostly in the normal category 30 people, $63.8 \%$ ) and in the weight category as many as 9 people $(19.1 \%)$.

The results of blood glucose assessment, level of knowledge, fiber intake and physical exercise can be seen in the Table 2:

Table 2. Distribution of respondents based on blood glucose, level of knowledge, fiber intake and physical exercise.

\begin{tabular}{lll}
\hline \multicolumn{1}{c}{ Variable } & $\mathbf{n}$ & \% \\
\hline $\begin{array}{l}\text { Blood Glucose } \\
\text { Controlled }\end{array}$ & 16 & 34 \\
$\quad$ Not controlled & 31 & 66 \\
Knowledge Level & & \\
$\quad$ Good & 15 & 31.9 \\
$\quad$ Fair & 19 & 40.4 \\
$\quad$ Poor & 13 & 27.7 \\
Dietary Fiber Intake & & \\
$\quad$ Good & 15 & 31.9 \\
$\quad$ Poor & 32 & 68.1 \\
Physical Exercise & & \\
$\quad$ Good & 20 & 42.6 \\
Poor & 27 & 57.4 \\
\hline TOTAL & 47 & 100 \\
\hline
\end{tabular}

Source : Processed Primary Data, 2017

Based on Table 2 it can be seen that the blood glucose levels of most respondents are not controlled as much as 31 people (66\%). The level of knowledge of respondents was mostly in the fair category that was as many as 19 people (40.4\%). Fiber intake and physical exercise activities of the most respondents were in the category of less. Those were 32 people (68.1\%) and 27 people (57.4\%) respectively.

\section{Bivariate Analysis}

The relationship between knowledge level and glucose blood level

Frequency distribution of respondents according to the level of knowledge and blood glucose levels can be seen in Table 3. 
Spearman rank correlation test showed that therewas correlation between level of knowledge and blood glucose level of type 2 DM patient in Internal Medicine Polyclinic of RSUD Ulin Banjarmasin Hospital ( $p$-value $=0.000)$. It had Correlation Coefficient value -0.78 indicates the higher level of knowledge will decrease blood glucose levelwith a very strong level of tightness.

\section{The relationship of fiber intake to blood glucose} levels

The frequency distribution of respondents according to fiber intake, blood glucose levels, and its relationships can be seen in Table 4.

Spearman rank correlation test showed that there was correlation between fiber intake with blood glucose level of type 2 DM patient at RSUD Ulin Banjarmasin $(P=0.001)$. The Correlation Coefficient was -0.47 that showed the higher consumption of blood glucose fiber will lower the level of closeness between independent and dependent variables.

The relationship between physical exercise and blood glucose levels

The frequency distribution of respondents according to physical exercise and blood glucose levels can be seen in Table 5 .
Spearman rank correlation test showed that there was a correlation between physical exercise and blood glucose level of type 2 DM patient in RSUD Ulin Banjarmasin Hospital(Internal Medicine Polyclinic) ( $p=0.008)$. The Correlation Coefficient was -0.38 , indicating that the more physical exercise will decrease blood glucose levels with a moderate level of tightness.

\section{Multivariate Analysis}

To proceed into the multivariate analysis, the first logistic regression analysis of the variables of knowledge, fiber intake and physical exercise were done. The results obtained $p$ value $<0.25$ of the variable knowledge, fiber intake and physical exercise, therefore can be continued into multivariate analysis.

This will make the best model in the determining the determinant of blood glucose levels. Carried logistic regression was between knowledge, fiber intake and physical exercise.

All three variables were included in the model by looking at $p<0.05$, then the variable with the largest value was issued one by one, starting with the knowledge removed from the model with $p>$ 0.99 . The results obtained from fiber and physical exercise after the knowledge variables were

Table 3. The level of knowledge, on blood glucose levels, and telationship of patients with type 2 DM in Ulin Disease Polyclinic in Banjarmasin Year 2017

\begin{tabular}{|c|c|c|c|c|c|c|c|}
\hline \multirow{3}{*}{$\begin{array}{c}\text { Knowledge } \\
\text { level }\end{array}$} & \multicolumn{4}{|c|}{ Blood Glucose Level } & \multirow{2}{*}{\multicolumn{2}{|c|}{ Total }} & \multirow{3}{*}{$\mathbf{r}$} \\
\hline & \multicolumn{2}{|c|}{ Controlled } & \multicolumn{2}{|c|}{ Not Controlled } & & & \\
\hline & $\mathbf{n}$ & $\%$ & $\mathbf{n}$ & $\%$ & $\mathbf{n}$ & $\%$ & \\
\hline Good & 14 & 93.3 & 1 & 6.7 & 15 & 100 & \\
\hline Fair & 2 & 10.5 & 17 & 89.5 & 19 & 100 & -0.783 \\
\hline Poor & 0 & 0 & 13 & 100 & 13 & 100 & \\
\hline Total & 16 & 34 & 31 & 66 & 47 & 100 & \\
\hline
\end{tabular}

$p=0.000, \alpha=0.05$

Table 4. Distribution of respondents according to fiber intake and blood glucose levels of patients with Type 2 Diabetes Mellitus in the Polyclinic of Internal Medicine RSUD Ulin Banjarmasin by the Year 2017

\begin{tabular}{|c|c|c|c|c|c|c|c|}
\hline \multirow{3}{*}{ Fiber Intake } & \multicolumn{4}{|c|}{ Blood Glucose Level } & \multirow{2}{*}{\multicolumn{2}{|c|}{ Total }} & \multirow{2}{*}{$\mathbf{r}$} \\
\hline & \multicolumn{2}{|c|}{ Controlled } & \multicolumn{2}{|c|}{ Not Controlled } & & & \\
\hline & $\mathbf{n}$ & $\%$ & $\mathbf{n}$ & $\%$ & $\mathbf{n}$ & $\%$ & \multirow{4}{*}{-0.471} \\
\hline Good & 10 & 66.7 & 5 & 33.3 & 15 & 100 & \\
\hline Poor & 6 & 18.8 & 26 & 81.3 & 32 & 100 & \\
\hline Total & 16 & 34 & 31 & 66 & 37 & 100 & \\
\hline
\end{tabular}

$p=0.001, \alpha=0.05$ 
Table 5. Distribution of respondents according to physical exercise and blood glucose level of type 2 DM patient in RSUD Ulin Banjarmasin Internal Medicine Clinic by the Year 2017

\begin{tabular}{|c|c|c|c|c|c|c|c|}
\hline \multirow{3}{*}{$\begin{array}{l}\text { Physical } \\
\text { Excercise }\end{array}$} & \multicolumn{4}{|c|}{ Blood Glucose Level } & \multirow{2}{*}{\multicolumn{2}{|c|}{ Total }} & \multirow{2}{*}{$\mathbf{r}$} \\
\hline & \multicolumn{2}{|c|}{ Controlled } & \multicolumn{2}{|c|}{ Not Controlled } & & & \\
\hline & $\mathbf{n}$ & $\%$ & $\mathbf{n}$ & $\%$ & $\mathbf{n}$ & $\%$ & \multirow{4}{*}{-0.381} \\
\hline Good & 11 & 55 & 9 & 45 & 20 & 100 & \\
\hline Poor & 5 & 18.5 & 22 & 81.5 & 27 & 100 & \\
\hline Total & 16 & 34 & 31 & 66 & 47 & 100 & \\
\hline
\end{tabular}

$p=0.008, \alpha=0.05$

Table 6. Results of multivariate logistic regression analysis between fiber intake and physical exercise on blood sugar levels

\begin{tabular}{lcccc}
\hline \multicolumn{1}{c}{ Variable } & $\mathbf{B}$ & $\mathbf{p}$ & OR & $\mathbf{9 5 \% ~ C l}$ \\
\hline Fiber Intake & 2.243 & 0.005 & 9.418 & $2.001-44.341$ \\
Physical Excercise & 1.778 & 0.022 & 5.917 & $1.296-27.017$ \\
\hline
\end{tabular}

excluded. Obtained fiber intake result were $p=0.005$ with value of $O R$ was 9.418 and physical exercise value $p=0.022$ with OR 5.917 .

The multivariate result showed that variables of fiber intake and physical exercise had $p<0.05$. It mean that both variables were significantly related to blood glucose levels. The next analysis was to assess whether the two variables interact with interaction test. Obtained $p$ value interaction was $(x 2)=0.000(p<0.05)$. This suggests that the relationship between fiber intake and blood glucose levels showed different effects with that between physical exercise and blood glucose levels.

The results of the overall analysis showedthat amongthe three variables that are suspected to be associated with blood glucose levels, fiber intake has a chance to control blood glucose levels 9.418 times (95\% Cl: 2.001-44.341) and physical exercise could potentially control blood glucose levels 5,017 times $95 \% \mathrm{Cl}: 1.296-27.017)$. Furthermore, it could be concluded that fiber intake is the most dominant variable associated with blood glucose levels.

\section{DISCUSSION}

\section{Characteristic description of respondents}

Almost all respondents aged early and advanced (46-65 years) as many as 41 people (87.3\%) and most of them were of female. Age $\geq 45$ years had an increased risk of DM and glucose intolerance caused by degenerative factors that decrease body function, especially the ability of $\beta$ cells in producing insulin to metabolize glucose (12).

Women were more at risk of diabetes because they have a greater chance of increasing their body mass index. The existence of monthly cycle syndrome (premenstrual syndrome), postmenopouse that made the distribution of body fat become easily accumulated due to hormonal process(13). In addition, women's physical activity factors were lower than in men be cause by increas fat, someone had the risk of increasing blood glucose levels(15)

Nutritional status of many normal respondents and excess ofbody height based on BMI were included in mild and moderate level weight gain (15). High free fat deposits can cause healthy selfesteem to free fatty acids and spur fat oxidation that will eventually use glucose in the muscle (17). This is a lot happening in pregnant women housewives who fall into the category of light activity (18). Light activity can cause fat accumulation in the body that can suppress insulin and lead to increas of blood glucose levels of patients with type 2 DM (19).

In addition to housewives, the incidence of blood glucose levels increase of respondents working in their own field and civil servants that was in the category of light activity may be caused by high workload that resulted in stress. Stress affects blood glucose levels as well as the condition 
of respondents who in a state of stress can lead to dietary changes such as eating lots of foods high in carbohydrates $(20,21,22)$. This is in accordance with Andi 2007 in Trisnawati Shara in 2013 that reported people who experience stress had a risk of 1.67 times to higher suffer from type 2 DM compared to people who do not experience stress(23).

Respondents with low-and middle-level education may have limited knowledge, which may impact on the choice of inappropriate food and uncontrolled eating patterns(24).

\section{Univariate analysis}

Description of blood glucose levels

Controlled Fasting blood glucose levels by the 2013 consensus were $<126 \mathrm{mg} / \mathrm{dL}$ (3). In this study, the number of uncontrolled more than that of controlled. This was in line with research in the Polyclinics of Internal Medicine of RSJ Prof. Dr. Soerojo Magelang that of 86 respondents,(61.6\%) had uncontrolled blood glucose levels (25).

Insulin resistance is a heterogeneous syndrome, with genetic and environmental factors playing an important role in its development. Other factors such as lack of physical activity, foods containing fat, also expressed related to the development of obesity and insulin resistance (26).

\section{An overview of the level of knowledge}

The result of this research was in line with Unik Sri's research, et al (2012) that found among 53 respondents $35.8 \%$ of respondent had high knowledge level and $37.7 \%$ respondent have less level of knowledge about DM disease. To optimize individual knowledge, they required health education through communication or group dynamics $(27,28)$.

Knowledge of respondents that was in the middle category included in knowing about insulindependent diabetes DM is included type 2, often feel hungry so much to eat (polypagia) is a symptom of diabetes. DM can lead to kidney disorders and visual impairment. To prevent DM disease were consume the recommended foods, exercising and controlling blood glucose levels, taking medicine as directed by a doctor. Knowledge of respondents in the less category they cause of DM disease as well as complications were included in knowing and blood glucose levels $<200 \mathrm{mg}$ / dL was called normal blood glucose levels $(29,30)$.

\section{Description of fiber intake}

This research was in line with research in the Polyclinic of Internal Medicine Dr. H. Abdul Moeloek Lampung Province that reported the knowledge of DM patients about knowing fiber intake was $85.4 \%$ in the category of less and $14.6 \%$ of respondents in good category $(31,32)$.

Fiber could help the absorption of glucose in the blood and slow the release of glucose in the blood. American Diabetes Association recommends fiber intake for patients with DM is $>25 \mathrm{~g}$ per day $(33,34,35,36)$.

\section{Picture of physical exercise}

The results of this study were in line with the research at Primary Health Centers Pacar Keling on 20 cases of DM patients. All respondents who carry out physical exercise with less intensity and quite were more than respondents who do not carry out physical exercise at all $(37,38)$. The low frequency and duration of physical exercise were related to various factors such as workload and age factor. Age factors may be associated with reduced muscle mass and obesity (37).

\section{Analysis of the interrelationship of knowledge variables, fiber intake and physical exercise on blood glucose levels.}

The data were collected using a questionnaire consisting of 18 question items. $100 \%$ of respondents know that activities such as walking can control blood glucose levels.

Respondent consisted of 7 people $(43.8 \%)$ with controlled blood glucose status and 24 people $(77.4 \%)$ with uncontrolled blood glucose status responded to other symptoms besides eating, drinking, and urinating. In addition, respondents also know about the occurrence of weight loss (38).

From the quistionons about the knowledge of the recommended/restricted foods, found that 25 respondents (53.2\%), consisted of 6 people (37.5\%) of respondents with controlled blood glucose status 
and 19 people $(61.3 \%)$ of respondents with glucose level uncontrolled blood answered the sponge was a snack that can be consumed. This shows their lack of knowledge that the fact that sponge is not recommended for consumption of people with diabetes mellitus, because the manufacture of sponge, wheat flour into the main material that has a value of 70 glycemic index belonging to a high glycemic index $(33,39)$.

The results of this study bivariate indicate that there was a relationship between the level of knowledge and blood glucose level of type 2 DM patient in the Polyclinic of Internal Medicine Ulin Banjarmasin Hospital. This relationship was negative where the higher the level of knowledge, the lower the blood glucose level. The lower the knowledge, the higher the blood glucose level. The low knowledge of the respondents about DM disease give the impact on disable in controling blood glucose levels and cause blood glucose levels to be high (40). This was in accordance and other opinions that a significant relationship between the level of knowledge with blood glucose levels. The results obtained that the respondents who have low knowledge about DM had poor understanding about diabetes $(28,30,40)$. However, multivariate model with knowledge turned out not related to blood glucose levels. There were other variables, namely fiber intake and physical exercise that can dominantly control blood glucose levels.

The data of fiber intake was taken using food recall questionnaire $1 \times 24$ hours. The average patient had an inadequate diet schedule, type, and amount. About $83 \%$ of patients tended to restrict food with a diet of $<3 x$ main meal / day with or without snack. This diet disorder affected the fiber intake of food. The lowest intake of fiber from 47 respondents was $1.70 \mathrm{~g}$ with the status of fasting blood glucose included in uncontrolled. This was because the patient's diet wasonly 2 times a day without food interlude and did not consume enough vegetables and fruits that tended to have a high fiber content.

The highest fiber intake was $37.82 \mathrm{~g}$ with a controlled blood glucose status. This was because respondents have a $3 x$ main meal pattern and $3 x$ to eat a distraction. In addition, the type of food used was low in carbohydrates, such as brown rice, vegetable mustard, carrots, soybean tempe, papaya, guava, pear. Each of these foods had high fiber and available at mealtime.

The average fiber intake of all respondents was $20.29 \mathrm{~g}$. Sources of fiber from the type of vegetables consumed by respondents were carrots, long beans, spinach, mustard, sprouts, and cabbage. Sources of fiber from the types of fruits that were often consumed by respondents were bananas, papaya and apples. However, the source of fiber intake was not meet the needs of fiber every day because the fruits are not always available in the daily menu.

Eating a high in fiber diet is able to control blood glucose and reduce the need for insulin. Consumption of fiber, especially insoluble fiber (embodied fiber) contained in grains and some plants, can help to prevent the occurrence of diabetes by increasing the working of the hormone insulin in regulating blood glucose in the body. Insoluble fiber is insoluble in water and can pass through the digestive system as a whole can serve as a feeling of fullness and satisfaction and help control appetite (16).

The results of this study indicate that there was a correlation between fiber intake level to blood glucose level of type 2 DM patient in Ulin Banjarmasin Internal Medicine Polyclinic. This relationship was negative where the higher the fiber intake the lower the blood glucose level. This result was in line with research that states that there was a significant relationship between fiber consumption with fasting blood glucose levels (29). This concurred with another study that states that patients who had a good fiber intake will experience a decrease in blood glucose levels in patients with type 2 DM (26). When food enters the body, the fiber was not digested by the body. The fiber just passes through the digestive tract. This makes fibrous foods less likely to cause an increase in blood glucose levels. Meta-analysis of 15 studies showed that fiber intake could reduce fasting blood glucose and hemoglobin A1c (32). The result of multivariate analysis of fiber had a significant relationship to 
blood glucose level and the most dominant chance to blood glucose level.

The physical exercise data retrieval was taken using a questionnaire, the items available were the type of physical exercise, the frequency and duration. A total of 34 respondents $(72.3 \%)$ chose walking as a physical exercise activity because walking was easier to do and less dangerous. Done in the morning. This was also due to the age of the respondents in the final elderly category $(51.1 \%)$.

Physical exercise that is performed regularly for approximately 30 minutes with a frequency of three to four times a week is one pillar in the management of type 2 Diabetes Mellitus. The influence of physical activity in physical exercise is directly related to increased speed of muscle glucose recovery (how much muscle taking glucose from the bloodstream). When performing physical exercise, the muscles use glucose stored in the muscle and if glucose is reduced, the muscles fill the void by taking glucose from the blood. This will result in decreased blood glucose thus improving blood glucose control (41).

The results of this study indicated that there was a relationship between physical exercise to blood glucose levels of patients with Type 2 Diabetes Mellitus in the Polyclinic of Internal Medicine Ulin Banjarmasin Hospital. This relationship is negative where the higher the duration and frequency of physical exercise, the lower the blood glucose level. The results of this study were in consistent with a study that states the frequency and duration of physical exercise was significantly associated with fasting blood glucose and 2 hour postprandial blood glucose levels in which the longer the frequency and duration of physical exercise the lower fasting glucose and 2 hours postprandial blood glucose $(40,42)$.

Existence of physical exercise relation to blood glucose level in patient of Type 2 Diabetes Mellitus is proven, that blood glucose level of Type 2 Diabetes Mellitus patient after doing physical exercise in the form of gymnastic which lasted for 30 minutes was lower than that of before physical exercise. The results of this study indicated that an improvement in blood glucose control, and theoretically also showed an improvement in sensitivity of insulin receptors in the body of research subjects (32). The use of glucose as an energy source of muscle metabolism would increase 15 times after the duration of physical exercise for 10 minutes and 35 times in the duration of 60 minutes $(33,38)$. The mechanism of controlling blood glucose with physical exercise is when exercising the muscles of the muscles using glucose stored in the muscle and when the muscle glucose is reduced, the muscle will fill the muscle glucose deficiency taken from blood glucose, thereby enlarging the control of glucose in the blood $(43,44,45)$.

The results of the overall analysis that has been done was that only 3 variables fiber intake and physical exercise associated with blood glucose levels $(46,47,48)$. Knowledge could not always lower blood glucose levels if the behavior was not suitable for Type 2 Diabetes Mellitus. This was in line with research Fitri RI et al, that showed fiber intake and physical exercise affect the control of blood glucose $(30,34,50,51,52,53)$. Furthermore, it can be concluded that fiber intake was the most dominant variable associated with blood glucose levels $(34,45,36)$.

\section{CONCLUSIONS AND RECOMMENDATIONS}

In this study, fiber intake and physical exercise were closely related to blood glucose levels in outpatients with type 2 diabetes. Patients with type 2 diabetes are expected to increase their intake of fiber in daily food life vegetables and fruits, as well as increase physical exercise such as walking, jogging for 30 minutes at a frequency of 4-5 times a week. Education related to management in controlling blood glucose levels and prevention of complications of type 2 diabetes mellitus was given by the hospital, as well as information for further research by adding variables such as heredity, diet and to increase the number of respondents more.

\section{A conflict of interest statement}

The authors state there is no conflict of interest with the parties concerned in this study. 


\section{REFERENCES}

1. Gustian,R Diagnosis dan Klasifikasi Diabetes Melitus dalam Buku Ajar IImu Penyakit Dalam. Jakarta: Pusat Penerbitan Departemen IImu Penyakit Dalam FK UI. pp. 1857 - 1859. 2006.

2 . Complications of Diabetes. Available at: http:// www.idf.org/complications-diabetes

3. Perkeni. Konsensus Pengendalian Diabetes Mellitus tipe 2tipe 2 di Indonesia. Revisi ke 4: Jakarta. 2011.

4. Badan Penelitian dan Pengembangan Kesehatan Kementerian Kesehatan RI. Riset Kesehatan Dasar (Riskesdas) 2013 : Jakarta. 2013.

5. Basuki E. Penatalaksanaan DM Terpadu. Jakarta : Balai Penerbit Fakultas Kedokteran Universitas Indonesia. 2004.

6. Prabowo, S. Hubungan Antara Pengetahuan tentang Serat dengan Konsumsi Serat pada Penderita DM di Poli Penyakit Dalam RSUD Dr. Moewardi Surakarta.Karya Tulis IImiah D3 Gizi. Surakarta. 2004.

7. Ideris. Faktor-Faktor Yang Berhubungan Dengan Penyakit DM Pada Pasien Poliklinik Penyakit Dalam Di Empat Rumah Sakit Provinsi Kalimantan Selatan Tahun 2009. Tesis . Jakarta: Prog Pascasarjana Prog Studi IImu Kesehatan Masyarakat Universitas Respati Indonesia. 2019.

8.. Presiden RI. Undang-Undang no.20, 2003,pasal 14. Jenjang Pendidikan Formal.

9. Supariasa IDN, dkk. 2014. Penilaian Status Gizi . Edisi 2 : Penerbit buku Kedokteran EGC.

10. Arikunto, S. Prosedur Penelitian Suatu Pendekatan Praktik. Ed Revisi. Jakarta : Rineka Cipta. 2010.

11. Ilyas, E. I. Olahraga bagi Diabetesi dalam: Soegondo, S., Soewondo, P., Subekti, I., Editor. Penatalaksanaan Diabetes Melitus Terpadu bagi dokter maupun edukator diabetes. Jakarta: Fakultas Kedokteran Universitas Indonesia.2011.

12. .Hastono Sutanto Priyo. Analisis Data. Modul Praktek. Jakarta: Fakultas Kesehatan Masyarakat Universitas Indonesia. 2001.

13. Pangemanan dan Malayu. Analisis Faktor Resiko Penyebab Terjadinya Diabetes Mellitus tipe 2tipe 2 Pada Wanita Usia Produktif Di Puskesmas Wawonasa. Jurnal e-Biomedik (eBM). Volume 2 Nomor 2. Manado : Fakultas Kedokteran Universitas Sam Ratulangi. 2014.

14. Ndraha Suzanna. Diabetes Melitus Tipe 1dan tatalaksana terkini . Mediciunus 9: vol 27 bol 27, No.2, Agustus 2014

15. Damayanti, A. Prevalensi dan Faktor Risiko Kejadian Diabetes Melitus di Daerah Urban Indonesia. Tesis. Jakarta : FKM UI. 2010.

16. Trisnawati Shara, Soedijono Setyorogo, Faktor Risiko Kejadian DM tipe II di Puskesmas Kecamatan Cengkareng Jakarta tahun 2012. Jurnal IImiah Kesehatan 5 (1): Januari 2013.

17. . Agustinah, Nurul. Hubungan Indeks Massa Tubuh (IMT) dengan Kadar Glukosa Darah Penderita DM di Desa Barengkrajan Kecamatan Krian Kabupaten Sidoarjo. Jurnal . Politeknik Kesehatan Majapahit. 2015.

18. Adnan Miftahul, dkk. Hubungan Indeks Massa Tubuh (IMT) dengan Kadar Glukosa Darah Penderita DM (DM) Tipe 2 Rawat Jalan Di RS Tugurejo Semarang. Jurnal Gizi UMS Volume 2 Nomor 1. Semarang: Prog Studi Fakultas IImu Keperawatan dan Kesehatan Universitas Muhammadiyah Semarang. 2013.

19. Soewondo P. Hidup Sehat dengan Diabetes. Jakarta : Balai Penerbitan FK UI. 2007.

20. Adnan Miftahul, Tatik Mulyati, Joko Teguh Isworo. Hubungan Indeks Massa Tubuh (IMT) dengan kadar Glukosa darah penderita Diabetes Mellitus tipe 2(DM) Tipe 2 Rawat Jalan di RS Tugureju Semarang. Jurnal Gizi universitas Muhammadiyah Semarang, Vol 2, No.1 tahun 2013.

21. 20..Chandra Adrian Putradinata .Gbaran Riwayat Diabetes Melitus Keluarga, Indeks Massa Tubuh dan Aktivitas Fisik pada Penderita Diabetes Melitus Tipe 2 di Wilayah Kerja Puskesmas Manggis tahun 2013. E jurnal Medika Udayana. June 2015. ISSN

22. Witasari Ucik, Setyaningum Rahmawaty, Siti Zulaekah. Hubungan Tingkat Pengetahuan, Asupan Karbohidrat dan serat dengan Pengendalian Kadar Glukosa Darah Pada Penderita Diabetes Melitus Tipe 2. Jurnal 
Penelitian Sains \& Teknologi Volume 10, No2, 2009: 130-138.

23. Sheri R. Colberg, PHD, FACSM1, Ronald J. Sigal, MD, MPH, FRCP(C)2, Bo Fernhall, PHD, FACSM3, Judith G. Regensteiner, PHD4, Bryan J. Blissmer, PHD5, Richard R. Rubin, PHD6, Lisa Chasan-Taber, SCD, FACSM7, Ann L. Albright, PHD, RD8 and Barry Braun, PHD, FACSM9. Exercise and Type 2 Diabetes. Diabetes Care 2010 Dec; 33(12): e147-e167. https://doi.org/10.2337/dc10-9990 .http://care. diabetesjournals.org/content/33/12/e147. 19 nopember 2017.

24. Trisnawati Shara Kurnia, Soedijono Setyorogo1. Faktor RIsiko Kejadian Diabetes Melitus Tipe II di Puskesmas Kecamatan Cengkareng Jakarta Barat Tahun 2012. Jurnal IImiah Kesehatan, 5 (1): Jan 2013.

25. Notoatmodjo, Soekidjo. Pendidikan Dan Perilaku Kesehatan. Rineka Cipta. Jakarta. 2007.

26. Catur Mei, Asih S. Faktor-faktor Yang Berhubungan dengan Pengendalian Kadar Glukosa Darah Pasien Diabetes Mellitus tipe 2tipe 2 Rawat Jalan di Poliklinik Penyakit Dalam RSJ Prof.Dr.Soerojo Magelang Tahun 2013. Jurnal. Jakarta : Prog Studi Gizi, Fakultas Kesehatan Masyarakat Universitas Indonesia. 2013.

27. Jafar N . Penangglukosangan Diabetes Mellitus tipe 2tipe 2. Makalah IImiah. Makassar : Prog Studi Ilmu Gizi Fakultas Kesehatan Masyarakat Universitas Hasanuddin. 2009.

28. Unik Sri, dkk. KorelasiAntara TingkatPengetahuan dan Kepatuhan Diet Dengan Terkontranya Kadar Glukosa Darah Pada Penderita DM Tipe II di Desa Nyatyono Kecamatan Ungaran Barat Kabupaten Semarang. Jurnal Semarang : Prog studi IImu Keperawatan Stikes Ngudi Waluyo. 2012.

29. Agustina, T. Gbaran Sikap Pasien DM Di Poli Penyakit Dalam RSUD Dr.Moewardi Surakarta Terhadap Kunjungan Ulang Konsultasi Gizi. KTI. Surakarta : Jurusan Gizi Fakultas IImu Kesehatan Universitas Muhammadiyah Surakarta. 2009.

30. Faidah NN dan Estiasih T. Aplikasi bubuk pewarna berantioksidan dari limbah teh untuk biskuit hipoglikemik substitusi tepung suweg. $J$ Teknol Pert. 10(3). 2009.

31. Misdarina, Yesi Arina. Pengetahuan DM Dengan Kadar Glukosa Darah Pada Pasien Diabetes Mellitus tipe 2tipe 2. Junal. Medan : Fakultas Keperawatan Universitas Sumatera Utara. 2009.

32. Muliani,Usdeka. Asupan Zat-Zat Gizi Dan Kadar Glukosa Darah Penderita DM-Tipe 2 Di Poliklinik Penyakit Dalam RSUD Dr.H.Abdul Moeloek Provinsi Lampung. Jurnal Kesehatan, Volume IV, Nomor 2,Oktober 2013, hIm 325-332. Lampung : Jurusan Gizi Poltekkes Kemenkes Tanjungkarang. 2011.

33. Fitri RI, Yekti W. Hubungan Konsumsi Karbohidrat, Konsumsi Total Energi, Konsumsi Serat, Beban Glikemik, dan Latihan Jasmani Dengan Kadar Glukosa Darah pada Pasien Diabetes Mellitus tipe 2tipe 2. Artikel Asli Vil. 46 No.2 . Semarang : Prog Studi IImu Gizi Fakultas Kedokteran.

34. Indriyani Puji, Heru Supriyatno, Agus Santoso. Pengaruh Latihan fisik senam Aerobik Terhadap Penurunan kadar Glukosa Darah Pada Penderita Diabetes Melitus Tipe 2 di wilayah Puskesmas Buka teja Purbanlingga. Nurse Media, Junal of Nursing, Vol 1, No. 2 tahun 2007.

35. intanahSufiati B , Erma Handarsari. Asupan Serat dengan Kadar Gula darah, Kadar Kolesterol Tolat dan Status Gizi Pada Pasien Diabetes Mellitus Tipe 2di Rumah Sakit Roemani Semarang. Seminar Hasil-Hasil Penelitian - LPPM UNIMUS 2012.

36. AgusSantoso. Serat Pangan dan Manfaatnya Bagi Kesehatan. Magistra, No 75 tahun XXIII Maret 2011.

37. KushartoClara Meliyanti. Serat Makanan dan Perannya Bagi Kesehatan. Jurnal Gizi Dan Pangan. Volume 1 No 2 (2006).

38. Putri Laili, E. Hubungan Antara Latihan Jasmani Dengan Kadar Glukosa Darah Penderita Diabetes. Surabaya: Fakultas Kesehatan Masyarakat Universitas Airlangga. 2015.

39. Rosyada Amrina Indang Trihandini. Determinan Komplikasi Kronik Diabetes Melitus pada Usia Lanjut. Natonal Public Health journal vol 7 No 9 April 2013. 
40. Agustina, T. Gbaran Sikap Pasien DM Di Poli Penyakit Dalam RSUD Dr.Moewardi Surakarta Terhadap Kunjungan Ulang Konsultasi Gizi. KTI. Surakarta : Jurusan Gizi Fakultas IImu Kesehatan Universitas Muhammadiyah Surakarta. 2009.

41. Jazilah, Paulus Wijono dan Toto Sudargo. Hubungan Tingkat Pengetahuan, Sikap Dan Praktik(Psp) Penderita Diabetes Mellitus Mengenai Pengelolaan Diabetes Mellitus Dengan Kendali Kadar Glukosa Darah. Sains Kesehatan 2003, vol XVI, No. 23.

42. Rositalis, and Dewi Marhaeni. DH, and Kuswandewi Mutyara. Konseling Gizi Transtheritical Model Dalam Mengubah Perilaku Makan dan Aktivitas Fisik Pada Remaja Overweight dan Obesitas. Kajian Literatur. Prog Studi Magister IImu Kesehatan Masyarakat Bandung.

43. HandajaniAdianti, Betty Roosihermatie, Herti Maryani. Faktor-faktor yang Berhubungan dengan Pola Kematian pada Penyakit Degeneratif Di Indonesia. Buletin Penelitian Sistem Kesehatan Indonesia Vol 13, No 1 Jan (2010).

44. Mega Paramitha Gumilang. Hubungan Aktivitas Fisik dengan Kadar Glukosa Darah Pada Pasien Diabetes Melitus Tipe 2 di rumah Sakit Umum Daerah Karanganyar. Fakultas Kedokteran Universitas Muhamadyah Surakarta.

45. AdnanMiftahul, Tatik Mulyati, Joko Teguh Isworo. Hubungan Indeks Massa Tubuh (IMT) Dengan Kadar Gula Darah Penderita Diabetes Mellitus (DM) Tipe 2 Rawat Jalan Di RS Tugurejo Semarang. Jurnal Gizi Vol 2, No 1 (2013)

46. Lipoeto,Nur Indrawaty ; Eti Yerizel; Zulkarnain Edwarddan Intan Widuri.

47. Hubungan Nilai Antropometri dengan Kadar Glukosa Darah. Medika, Januari 2007, hal $23-28$.

48. Anam, MS. Pengaruh Intervensi Diet dan Olahraga Terhadap Indeks Massa Tubuh,
Kesegaran Jasmani dan Profil Lipid pada Anak Obesitas. Thesis, Universitas Diponegoro, 2010.

49. Soetiarto Farida, Roselinda Roselinda, Suhardi Suhardi. Hubungan Diabetes Melitus Dengan Obesitas Berdasarkan Indeks Massa Tubuh danLingkar Pinggang Data Riskesdas 2007. Buletin Penelitian Kesehatan Vol 38, No 1 Maret (2010).

50. Fatima Restyana Noor. Diabetes Melitus Tipe. Fakultas Kedokteran Universitas Lampung Vol 4 Nomor 5 tahun 2015.

51. Sabena Eli. Hubungan Indek Massa Tubuh, Rasio Lingkar Pinggang Panggul, Konsumsi Energi Dan Karbohidrat Dengan Kadar Glukosa Darah Pada Penderita Baru DMTTI Rawat Jalan (Studi di RSU Tidar Magelang. Thesis FKM Universitas Diponegoro, 2003.

52. PutriNurlaili Haida Kurnia, Muhammad Atoillah Isfandiari. Hubungan Empat Pilar Pengendalian Diabetes Mellitus tipe 2tipe 2 Dengan Rerata Kadar Gula Darah. http://www.journal.unair. ac.id/filerPDF/jbed89640f867full.pd. diakses tanggal 19 Nopember 2017.

53. FauziLukman. Intensitas Jalan Kaki Terhadap Penurunan Kadar Glukosa Darah. Jurnal Kesehatan Masyarakat,KEMAS 8 (2) (2013) 106-112

54. Gusti Rizaniansyah Rusli, Septi Farianingsih. Senam Kaki Diabetes Menurunkan Kadar Gula Darah Pasien Diabetes Mellitus Tipe 2. Journals Of Ners Community Vol 6 No 2, 2015 http://journal.uniges.ac.id/index.php/JNC/issue/ view/27.

55. Anita Dyah Listyarini, Ana Fadilah. Brisk Walking dapat menurunkan Kadar Glukosa Darah Pada Penderita Diabetes Mellitus di Desa Klumpit Kecamatan Gebog Kabupaten Kudus. Jurnal Keperawatan dan Kesehatan Masyarakat Cendekia Utama. Vol 6 No 2, 2017. 